\title{
Álcool combustível e biodiesel no Brasil: quo vadis?
}

\author{
Luiz Fernando Paulillo* \\ Carlos Eduardo de Freitas Vian** \\ Pery Francisco Assis Shikida** \\ Fabiana Tanoue de Mello***
}

Resumo: O objetivo deste estudo é fazer uma análise das cadeias agroenergéticas do álcool combustível e do biodiesel no Brasil, à guisa do referencial neocorporativista. Como resultado, um dos desafios da cadeia brasileira do álcool é apurar as dimensões do mercado externo e interno de álcool que se vislumbram, para viabilizar um planejamento estratégico de expansão da oferta de cana e de álcool. Já a cadeia do biodiesel depende, assim como o Proálcool em seus primórdios, de um paradigma subvencionista em sua fase inicial. Seu futuro está atrelado ao comportamento do preço do petróleo e da direção que irá tomar a orquestração de interesses em torno do biodiesel.

Palavras-chave: agroenergia, álcool, biodiesel, Brasil, neocorporativismo.

\footnotetext{
* Professor Doutor do Departamento de Engenharia da Produção da Universidade Federal de São Carlos, Centro de Ciências Exatas e de Tecnologia. dlfp@power.ufscar.br ** Professor Doutor do Departamento de Economia, Administração e Sociologia da ESALQ/USP, Coordenador do Grupo de Extensão e Pesquisa em História da Agricultura e dos Complexos Agroindustriais (GEPHAC) e do Grupo de Estudos e Extensão em Desenvolvimento Econômico e Social (GEEDES). cefvian@esalq.usp.br

*** Professor Associado da Universidade Estadual do Oeste do Paraná, Centro de Ciências Sociais Aplicadas. Bolsista de Produtividade em Pesquisa do CNPq e Pesquisador do GEPEC.pfashiki@unioeste.br

**** Mestre e Doutoranda em Engenharia de Produção - UFSCar. Centro de Ciências Exatas e de Tecnologia. fabianaortiz@uol.com.br

Os autores são gratos aos pareceristas desta Revista pelas profícuas sugestões e comentários.
} 
Classificação JEL: Q13, Q42.

Abstract: The objective of this study is to make an analysis of the agroenergy chains of the alcohol fuel and bio-diesel, based on the neo-corporativism reference. As a result, one of the challenges of the Brazilian alcohol chain is to select the dimensions of the external and internal market of alcohol that comes out, to make possible a strategically planning of expansion of the offer for sugar cane and alcohol. And the chain of biodiesel depends, as well as the Proalcohol in its genesis, on a subvention paradigm in its initial phase. Its future depends on the behavior of oil price and on the direction that the orchestra of interests around bio-diesel.

Key words: agro-energy, alcohol, bio-diesel, Brazil, neo-corporativism.

JEL Classification: Q13, Q42.

\section{Introdução}

O objetivo deste estudo é fazer uma análise, à guisa do referencial institucional das redes políticas neocorporativistas, das duas principais cadeias de agroenergia brasileira, a do álcool combustível e a do biodiesel. No primeiro caso, porque é um produto com mercado desenvolvido, em função da produção e do consumo interno em larga escala, além da inserção do país no comércio internacional. No tocante ao biodiesel, embora com uma produção interna ainda incipiente, trata-se de uma fonte de energia da biomassa com potencial de expansão nos próximos anos, tendo em vista a legislação já aprovada de adicionar $2 \%$ no óleo de petróleo a partir de 2008 e $5 \%$ em 2013. A partir desta análise, possíveis cenários e recomendações de políticas públicas serão ensejadas. A questão central é: álcool combustível e biodiesel, quo vadis?

O álcool, empregado na indústria química, fabricação de bebidas e como carburante (o foco deste trabalho é nesta função), é hoje a principal bioenergia utilizada no mundo. Entre 2000 e 2004, sua produção mundial cresceu 46,8\%, quando atingiu 41 bilhões de litros, dos quais quase $73 \%$ foram usados como combustível. Os maiores produtores de álcool são também os maiores consumidores - juntos, Brasil e Estados Unidos, fo- 
ram responsáveis por quase $70 \%$ da produção e do consumo mundial de 2004, seguidos pela China (8,9\%), União Européia (5,3\%) e Índia (4\%), que utilizam o biocombustível misturado à gasolina em diferentes percentuais (F.O.LICHT, 2005). Com uma demanda interna de 13 bilhões de litros, o mercado americano de álcool foi o que mais cresceu nos últimos anos, em função da substituição do MTBE (metil tércio butil éter) pelo bioetanol como oxigenador da gasolina em vários estados. A expansão da demanda americana tem sido respaldada pelo crescimento da oferta de milho no país e pela expansão da capacidade produtiva instalada. O Brasil, líder na produção e consumo de álcool, teve na safra 2006/07 uma produção recorde de 17,7 bilhões de litros, dos quais $80 \%$ foram destinados ao mercado interno e $20 \%$ ao externo. O crescimento atual assenta-se, mormente, nas vendas de veículos flexíveis (bicombustíveis).

No caso do biodiesel, os principais países produtores e consumidores são a Alemanha, França e Itália, possuindo subsídios para incentivar as plantações de matérias-primas agrícolas em áreas não exploradas, mais isenção de $90 \%$ nos impostos. Estes países possuem legislações aprovadas que estimulam o uso do biodiesel como oxigenador do óleo de petróleo num percentual de 5\%. Nos Estados Unidos os produtores também usufruem de incentivos tarifários e creditícios, em função da necessidade de dar vazão aos estoques extras de óleo de soja em vários estados, ajudando a equalizar o excesso de oferta agrícola para alimentação animal e humana (PAULILLO et al., 2006). Pode-se perceber aqui que a produção do biodiesel permite a continuidade das políticas agrícolas subvencionistas adotadas no Pós-Guerra. Outro fato é que os combustíveis são para uso em veículos e não para gerar energia.

Não obstante, a situação em que se encontra hoje a cadeia do álcool pode ser discutida a partir dos paradigmas vivenciados por esta cadeia e da orquestração de interesses que envolveu o Proálcool (Programa Nacional do Álcool), em que o locus de pressão de diferentes agentes contribuiu para a criação de lobbies e defesa de interesses (ALVES, 2002). Diga-se em escorço, os dois momentos elucidativos da cadeia do álcool foram: o do paradigma subvencionista (os mecanismos de regulação da atividade produtiva iam desde o estabelecimento de quotas de produção, fixação de preços, até a concessão de subsídios) e o do paradigma tecnológico (em que importa estar atento à apuração dos 
custos, ao desenvolvimento de novas tecnologias e aproveitamento de subprodutos como forma de definir o que é relevante para uma situação mais concorrencial) (SHIKIDA, 1997).

Este marco evolutivo da cadeia do álcool permite não só discutir suas perspectivas futuras como discutir também a cadeia do biodiesel. Ou seja, há a necessidade de um momento de paradigma subvencionista para o biodiesel? Poderá o biodiesel ter no futuro próximo o seu momento de paradigma tecnológico? Estará a cadeia do álcool entrando em uma nova fase de expansão?

Neste contexto, a análise neocorporativista é de grande valia para compreender o caráter funcional da relação entre grupos de interesses e o Estado, e seus comportamentos a partir dessa interação. Torna-se necessário avançar também no entendimento dos arranjos institucionais, derivados dos interesses organizados com as estruturas de decisão situados dentro do aparelho estatal. Dessa forma, esse procedimento contribui para elucidar os processos de formulação e implementação de políticas públicas (SHIKIDA et al., 2004).

Isto posto, este artigo contém cinco partes, incluindo esta introdução. Na seção dois são expostas breves notas sobre as redes políticas neocorporativistas, enquanto na seção três e quatro são feitas, respectivamente, as análises das cadeias do álcool e do biodiesel. Fechando este trabalho, seguem as considerações finais.

\section{Redes Políticas Neocorporativistas}

O neocorporativismo representa um arranjo institucional, ligando interesses organizados com as estruturas de decisão do Estado (BELIK, 1992). Segundo Paulillo (2002), as relações neocorporativistas caracterizam uma rede política em que pouquíssimas associações de interesses podem estabelecer relações estreitas com uma agência pública do Estado para a feitura de políticas públicas de um setor produtivo ou território.

Neste trabalho, o tipo neocorporativista de rede política será privilegiado porque nas agroindústrias sucroalcooleiras do Brasil (seja no Centro-Sul seja no Nordeste) existem poucas associações de interesses com recursos, habilidades e capacidades significativas para orquestrar políticas públicas junto ao Estado. Como a produção do biodiesel no 
Brasil é muito recente, e as próprias orquestrações somente agora começam a adensar, é fundamental partir do referencial de redes políticas neocorporativistas para compreender o tipo de jogo ou concerto que está se cristalizando em torno da produção do biodiesel, já que esta também é uma cadeia de agroenergia e está nascendo com as mesmas preocupações econômicas e sociais que a sucroalcooleira dos anos 70 .

A rede política neocorporativista apresenta "um tipo de interação (jogo de contrários) que pode produzir uma variedade de resultados ou arranjos dependendo das condições históricas particulares em que estas organizações foram geradas e se desenvolvem" (SAES, 1995, p.19). Para Marschall et al. (2005), com as redes políticas neocorporativistas as decisões políticas e econômicas não são definidas a partir do mercado livre e nem através de regras e normas impostas pelo Estado. Ou seja, a efetivação das políticas públicas não é resultado de decisões de cima para baixo. As decisões são tomadas a partir de relações ou concertos estratégicos de alguns poucos grupos de interesses e o Estado. Assim, as políticas e ações implementadas atendem aos interesses dos grupos organizados e do Estado, e não são apenas decisões de cunho técnico, envolvendo conseqüências políticas, financeiras, jurídicas, constitucionais, tecnológicas e simbólicas (PAULILLO, 2002).

Em redes políticas neocorporativistas, o princípio de orquestração de interesses fundamenta-se no núcleo da ordem corporativa-associativa, em que a satisfação dos interesses de seus agentes seria alcançada pelo ajuste mútuo e pelas interações repetidas (SAES, 1995). Esses interesses não são isentos de base econômica; ao invés, são habitualmente revestidos de propostas econômicas concretas que visam benefícios aos proponentes (BELIK, 1992).

Para implementação de pactos e compromissos estáveis nesse ambiente institucional neocorporativista, torna-se necessário que os agentes componentes dessa ordem possuam certo grau de simetria, não só de interesses, como de recursos de poder, capacitações e comportamentos (SAES, 1995; PAULILLO, 2002). Do contrário, o processo de tomada de decisão numa ordem neocorporativista torna-se vulnerável a conflitos e rupturas, posto a existência de incertezas a respeito do futuro dos compromissos. Os recursos de poder podem ser financeiros, tecnológicos, organizacionais, políticos, jurídicos e constitucionais e as 
capacidades podem ser desenvolvidas ao longo do jogo de orquestração das políticas públicas (PAULILLO, 2002).

Como essa simetria não é facilmente obtida no mundo capitalista, e como é comum cada lado objetivar resultados particulares durante os processos de ajustes de interesses, ocorre amiúde uma necessidade de intermediação do Estado. Este intercâmbio político neocorporativista envolve um processo de duplo sentido: "num deles, a representação dos interesses privados procura influenciar as autoridades do governo com o propósito de provocar decisões que a favoreçam; no sentido inverso, as autoridades governamentais procuram influenciar na articulação dos interesses privados" (SOTO, 1993, p.6-7). O Estado também pode repassar às associações algumas de suas tarefas.

Por um lado, a intermediação estatal vem corroborar o fato de o neocorporativismo representar uma forma de arranjo institucional (BELIK, 1992), por outro, capacita o próprio Estado, mediante esta interação, a implementar políticas setoriais com maior aval (SAES, 1995). Nesse contexto, a entrada do Estado para facilitar o jogo de interesses privados, no âmbito da rede política neocorporativista, justifica-se por duas razões: pelos relativamente baixos custos decorrentes dessa intermediação; e porque o próprio Estado estaria ampliando a sua área de atuação, modificando, em parte, o jogo de interesses de privado-privado para privado-público. Pode haver casos em que esse tipo de chamamento ao Estado não se verifica, pois este já é parte componente da ordem corporativa-associativa, com seus próprios interesses em jogo.

Um acontecimento que eventualmente pode ocorrer é o que Wilson e Butler (1985) rotularam de falso neocorporativismo, no qual o Estado assume a direção dos processos de decisões de determinada associação. Em outra situação, ou seja, diante das incertezas e inseguranças inerentes aos processos de tomada de decisão numa ordem neocorporativista, aumenta-se o risco de o Estado perder a sua autonomia. O que obstaculiza essa autoridade (domínio) sobre o Estado, segundo Streeck e Schmitter (1985), são as disputas entre os diversos grupos de interesses existentes dentro do aparelho estatal.

$\mathrm{Na}$ análise neocorporativista existem dois blocos de interesses: o privado - oriundo de segmentos da sociedade cujo domínio é particular; e o público - pertencente e/ou destinado à coletividade. Dentro 
do interesse público ainda se encontram os de Estado, do governo (do regime) e dos funcionários públicos.

Este trabalho recorre à análise institucionalista da rede política neocorporativista, em razão do seu poder de explicação para casos pertinentes às cadeias do álcool e biodiesel, dada a diversidade de interesses envolvidos, das poucas associações com poder de negociação perante o Estado e a própria necessidade da presença do Estado para mediar os conflitos.

\section{Cadeia do álcool}

\subsection{Aspectos econômicos da cadeia do álcool}

O Brasil é o maior produtor mundial de álcool, utilizando a canade-açúcar como matéria-prima. Na safra 06/07 colheu 426 milhões de toneladas de cana, sendo quase a metade destinada para a produção de álcool. Atualmente, são 70 mil agricultores em todo o Brasil e 393 usinas, distribuídas, principalmente, nas regiões Centro-Sul (responsável por $89 \%$ da produção de álcool) e Norte-Nordeste (11\% restantes).

A região Centro-Sul, que tem São Paulo como maior produtor, além de apresentar a maior produtividade agrícola e industrial e os menores custos de produção e de logística, está mais próxima do mercado consumidor, dos centros de pesquisa e da indústria de máquinas e equipamentos para o setor. Já as usinas e destilarias da região Norte-Nordeste, que exportam a maior parte da produção, têm encontrado dificuldades em se adaptar às novas condições técnicas impostas pela desregulamentação do setor, apresentando custos de produção mais elevados. Os grupos econômicos mais capacitados em termos financeiros e estratégicos têm investimentos em novas unidades no Centro-Sul (VIAN, 2003).

É nos países ricos e industrializados que reside o mercado potencial para as exportações brasileiras. Contudo, são mercados altamente protegidos, e qualquer avanço nesta área depende da abertura de mercados através de negociações. Nos Estados Unidos, segundo maior mercado consumidor de álcool, o governo assegura uma reserva de mercado para os produtores locais de milho. Esta proteção equivale praticamente ao custo de produção de álcool no Brasil. Como o nível de proteção é elevado, somente ocasionalmente é viável a exportação direta para o 
país, como ocorreu em 2004 - ou seja, quando os preços do álcool e da gasolina americana forem tão elevados que viabilizem as exportações brasileiras diretas para os Estados Unidos, mesmo pagando os impostos de importação. Na União Européia, além da restrição à importação do álcool brasileiro (tarifas entre 10,2 e 19,2 euro/hl), os produtores locais também contam com subsídios, afetando a competitividade do nosso combustível. Na União Européia existem pesquisas para fontes próprias de matérias-primas, tais como cereais, madeira etc.

No Brasil, a produção de álcool na safra 2006/07 foi recorde, 17,7 bilhões de litros, impulsionada pelo crescimento das vendas de veículos flexíveis ou bicombustíveis (flex fuel - gasolina e álcool). Desde quando os veículos flex foram lançados (em 2003), a produção vem crescendo e ganhando participação de mercado. Em termos de venda total de automóveis e comerciais leves das montadoras brasileiras, a participação do flex no total acumulado, de janeiro a junho de 2006, é de $51,7 \%$, conforme dados da Associação Nacional dos Fabricantes de Veículos Automotores (ANFAVEA, 2006).

É inconteste que, a partir dos últimos anos, vários fatores têm contribuído para aumentar a importância das fontes alternativas de energia no mundo, dentre os quais pode-se destacar: o questionamento dos efeitos do uso dos derivados do petróleo sobre o meio ambiente; o Protocolo de Kyoto (1997), que traça a política dos países sobre o meio ambiente, estabelecendo metas de controle das emissões de $\mathrm{CO}_{2}$ a partir de 2008; a instabilidade no Oriente Médio e a elevação real dos preços internacionais do petróleo ${ }^{1}$ e a necessidade dos países de reduzir a dependência deste combustível; os baixos preços das commodities e a busca de alternativas agrícolas e a possibilidade de geração de empregos. O Quadro 1 resume o estágio em que se encontram os programas de álcool em alguns países, ressaltando que alguns estão entrando em fase de produção a partir de matérias-primas locais.

${ }^{1}$ Salienta-se, contudo, que a estrutura de preços de derivados de petróleo no Brasil é baseada nos preços do mercado internacional, o que, nas condições atuais, eleva sobremaneira alguns insumos do processo de produção ("Custo-Brasil”). Neste caso, uma avaliação comparativa de preço dos substitutos do petróleo deveria ser feita com uma planilha que saliente os reais custos de produção da Petrobrás. Sobre isto, ver: Unica (2007). 
Quadro 1. Estágio dos programas de utilização de álcool no mundo

\begin{tabular}{|c|l|}
\hline País & \multicolumn{1}{|c|}{ Estágio } \\
\hline Brasil & $\begin{array}{l}\text { Exige 25\% de mistura à gasolina atualmente (legislação permite percentual entre 20\% } \\
\text { e 25\%). }\end{array}$ \\
\hline Estados Unidos & $\begin{array}{l}\text { Percentual de até 10\% em alguns estados, como é o caso da Califórnia, Nova York } \\
\text { e Minnesotta. }\end{array}$ \\
\hline União Européia & Até o final de 2005, exigirá 2\% de mistura. Percentual aumentará para 5,75\% em 2010. \\
\hline Canadá & $\begin{array}{l}\text { Exige 5\% de adição, devendo aumentar para 7,5\% até o final de 2005, e para 10\% em } \\
\text { alguns estados. }\end{array}$ \\
\hline Japão & $\begin{array}{l}\text { Já instituiu 3\% de mistura voluntária. Deve aumentar para 10\% até 0 próximo ano e } \\
\text { tornar a mistura compulsória. }\end{array}$ \\
\hline Índia & $\begin{array}{l}\text { Exige 5\% de mistura na gasolina. Objetivo é ter um modelo parecido com o do Brasil } \\
\text { (entre 20\% e 25\%). }\end{array}$ \\
\hline Colômbia & Exigirá 10\% de mistura em grandes cidades a partir de setembro/05. \\
\hline Tailândia & Exige mistura de 10\% em todos 0s postos de gasolina de Bangkok. \\
\hline China & Exige vários percentuais de mistura em várias províncias, chegando a 10\%. \\
\hline Venezuela & Criou programa que exige 5\% de mistura de etanol na gasolina neste ano. \\
\hline Argentina & Pretende implementar 5\% de mistura nos próximos 5 anos. \\
\hline
\end{tabular}

Fonte: Elaborado por Paulillo et al. (2006) a partir de dados do F.O. Licht (2005) e da Renewable Fuel Association (2004)

\subsection{Do paradigma subvencionista ao paradigma tecnológico ${ }^{2}$}

A agroindústria canavieira do Brasil sempre foi objeto de intervencionismo governamental, variando apenas de grau conforme as circunstâncias e interesses de cada época. Contudo, foi efetivamente a partir da criação do Instituto do Açúcar e do Álcool (IAA), na década de 1930, que o produtor da agroindústria canavieira passou a estar sujeito a uma série de arranjos institucionais que ligavam os interesses organizados do setor - sobretudo os do Nordeste - com as estruturas de decisão do Estado. Esse arranjo institucional, por um lado, proporcionava ao produtor, seja de que região fosse, um certo paradigma subvencionista como modelo de sobrevivência.

Um ponto de inflexão na agroindústria canavieira ocorreu na metade da década de 1970, quando houve a criação do Proálcool. Sua evolução pode ser melhor avaliada mediante estudo das suas fases. Assim, no período 1975-1979 dois pontos merecem ser acentuados. Primeiro, a crise

${ }^{2}$ Este texto é baseado, em grande parte, em Shikida (1997). 
do petróleo teve uma correlação positiva com a criação do Proálcool, não sendo, contudo, seu único determinante. A crise do petróleo gerou um "gargalo" no processo produtivo do mundo. Esse "gargalo" propiciou um ambiente favorável ao surgimento de opções energéticas alternativas. Contudo, a crise da agroindústria açucareira acabou favorecendo a orquestração de interesses que levou o Brasil a optar pelo Proálcool. Nessa linha de raciocínio, a crise do petróleo levou ao surgimento de várias inovações, e a orquestração de interesses definiu qual proposta foi vitoriosa.

Com efeito, o arranjo para viabilizar o Proálcool englobou os empresários das usinas e destilarias, o Estado, o setor de máquinas e equipamentos e a indústria automobilística. Para os usineiros tratava-se de diversificar a produção, de criar um novo mercado diante das crises da economia açucareira, e diante também de um parque produtivo que precisava avançar tecnologicamente e que estava com sobrecapacidade após a fracassada tentativa de aumento da inserção no mercado externo no final dos anos 60 e início dos anos 70.

Vale frisar, de acordo com Saes (1995), que para a implementação de pactos e compromissos estáveis, no contexto de neocorporativismo, torna-se necessário que os agentes integrantes dessa ordem possuam certo grau de simetria e de interesses. Como essa simetria não é facilmente obtida no mundo capitalista, e como é comum cada lado objetivar resultados particulares durante os processos de ajustes de interesses, ocorre a necessidade de intermediação do Estado. Este foi o caso do macrocorporatismo que envolveu o Proálcool.

Quanto ao segundo ponto que caracterizou o período 1975-1979, o que se confirmou na agroindústria canavieira com o início do Proálcool foi o fato do produtor estar novamente sujeito a uma série de arranjos institucionais patrocinados pelo Estado, o que lhe garantia um paradigma subvencionista como modelo de sobrevivência. Com isso, muitos dos produtores aí inseridos passaram a conviver com expedientes como reserva de mercado, concessão de subsídios, entre outros, que geravam boas margens de lucro. Se por um lado tal contexto foi bom para propiciar um maior desenvolvimento setorial, posto o arrefecimento forçado da concorrência, por outro lado contribuiu para a relativa falta de importância da tecnologia e do progresso técnico no interior desse setor (nessa fase). 
Cinco fatos, imbricados entre si, descrevem o período 1980-1985, quais sejam:

- o aprofundamento do "gargalo", provocado pela segunda crise do petróleo, propiciou um ambiente favorável para o lançamento de um novo produto (o álcool hidratado);

- a orquestração de interesses foi mais intensa vis-à-vis a primeira fase, direcionando-se para a produção de álcool hidratado, e estimulando o consumo do carro movido a álcool;

- diante desse novo ímpeto no Proálcool, impulsionado que foi por um elenco de políticas de crédito, subsídio e preços (que tinham por trás vastos recursos financeiros, na maioria públicos), verificou-se o fortalecimento da posição hegemônica de alguns empresários considerados inovadores na agroindústria canavieira e uma maior adesão de imitadores ao Proálcool;

- nessa segunda fase do Proálcool também ocorreu um período de preocupação com o desenvolvimento tecnológico na agroindústria canavieira, basicamente a partir de 1981-82 e que se prolongou até 1985, caracterizado pela busca de maior eficiência na conversão da sacarose no produto final e nas reduções de custo de produção.

O período 1986/1995 do Proálcool apresentou, inicialmente, um panorama de desaceleração, e depois, de crise. Houve uma substancial redução da participação dos investimentos públicos no Programa e desequilíbrio entre a oferta e a demanda de álcool combustível, o que acabou levando à redução do interesse em produzir (na ótica da indústria automobilística) e a comprar um veículo a álcool (na ótica do consumidor).

Mas, por que razão teria o Proálcool entrado numa fase tão crítica? Fazse necessário realçar que o "gargalo", oriundo da crise do petróleo, e que foi vital para o Proálcool, desapareceu. Assim, desapareceu a justificativa para manter o corporatismo em torno desse Programa. Outrossim, se o Proálcool obteve êxito com uma bem orquestrada junção de interesses, o seu malogro deveu-se também a uma rápida desagregação desses interesses: seja no âmbito do Estado, com tendência neoliberal e afetado por uma grave crise fiscal; seja na deserção da indústria automobilística e/ou na falta de interesse do consumidor pelo carro movido a álcool; e, seja na própria agroindústria canavieira, capaz de redirecionar parte da produção para o mercado açucareiro ao menor sinal de elevação dos preços internacionais. 
A crise do Proálcool, ocasionada pela instabilidade da produção alcooleira e a queda nas vendas de veículos movidos a álcool, contribuiu para avultar a heterogeneidade em termos produtivos existentes na agroindústria canavieira, posto que algumas empresas menos preparadas em termos de capacitação tecnológica encerraram suas atividades e/ou foram incorporadas pelas mais dinâmicas. "Um regime de maior liberdade de atuação deverá aumentar a participação no mercado das empresas mais eficientes que a média e com isso tornar o setor mais rentável" (FERNANDES e COELHO, 1996, p.154).

No panorama atual da agroindústria canavieira, já no século XXI, em um contexto de desregulamentação setorial, importa estar atento à apuração dos custos, ao desenvolvimento de novas tecnologias e aproveitamento de subprodutos, pois, quem está fazendo isto está se diferenciando dos demais, adotando o paradigma tecnológico como forma de definir o que é relevante para uma situação mais concorrencial.

Com efeito, a desregulamentação que afetou a agroindústria canavieira brasileira pós-1990, e que se aguçou no final da década de 1990 (com a liberalização dos preços), contribuiu para ampliar a eficiência e a competitividade do álcool brasileiro. Isso porque, com o fim do controle estatal, os produtores de álcool tiveram que se adaptar ao livre mercado e caminhar sem os incentivos, os subsídios e a coordenação do Estado. Nesse contexto, esses atores desenvolveram competências visando a geração de vantagens técnicas, enquanto, do ponto de vista institucional, a criação da CIDE (Contribuição de Intervenção no Domínio Econômico) tem contribuído para garantir a competitividade do álcool em relação à gasolina.

A legislação que regulamenta a eliminação da queimada da cana no principal estado produtor de álcool (São Paulo), na medida que exige a mecanização das operações agrícolas e logísticas, resulta na racionalização dos custos de produção em função da maior produtividade obtida. $\mathrm{O}$ aparato institucional de pesquisa e desenvolvimento (P\&D), concentrado em São Paulo, tem dado suporte à capacitação tecnológica para a produção agrícola e industrial, contribuindo, também, para elevar a produtividade na cadeia. Para viabilizar estas iniciativas, destaca-se o aparato dos bancos oficiais no financiamento da renovação tecnológica no campo e também no emprego de tecnologias de informação volta- 
das para a integração de processos gerenciais e para o planejamento de operações (VIAN, 2003).

Por outro lado, a legislação tornando compulsória a adição entre $20 \%$ e $25 \%$ de álcool anidro na gasolina, assegura uma reserva de mercado para o álcool, sem considerar a isenção fiscal para carros movidos exclusivamente a álcool. A adição de anidro à gasolina também permite que ajustes conjunturais sejam feitos com rapidez.

Além desse ambiente favorável, as inovações tecnológicas e organizacionais adotadas pelas usinas e destilarias brasileiras pós-desregulamentação estatal têm garantido a competitividade interna do álcool em relação à gasolina e, ao mesmo tempo, assegurado ao país a liderança em custos no mercado mundial do produto. Dentre as iniciativas no campo tecnológico e organizacional pode-se destacar: a) a implantação da automação microeletrônica no processamento industrial; b) a mecanização da atividade agrícola e das atividades de integração campoindústria; c) o estabelecimento de vínculos com fornecedores especializados de equipamentos e de serviços; d) as pesquisas para desenvolver variedades de cana mais produtivas; e) a terceirização de tarefas capital-intensivas, visando racionalizar custos operacionais; f) a estratégia de fusão ou aquisição de outras empresas para alcançar economias de escala e racionalizar os custos administrativos e os ligados à produção agrícola e industrial; g) a formação de grupos de comercialização de álcool no mercado doméstico e externo; h) a profissionalização administrativa das usinas e destilarias; i) a adoção de ferramentas gerenciais modernas; e, j) a criação do Sistema Consecana, regulamentando a compra e venda de cana-de-açúcar.

O Quadro 2 expõe uma síntese das fases vivenciadas pelo Proálcool e aspectos da orquestração de interesses que colocaram o álcool como um importante produto dentro da matriz energética brasileira (este quadro servirá para cotejo com o cenário atual do biodiesel).

Assim, pode-se dizer que o paradigma subvencionista para o álcool foi importante, proporcionou o crescimento do setor e a geração de renda. Mas, por outro lado, desigualdades regionais, concentração de renda, entre outras questões, não foram resolvidas. Nesta nova fase de expansão parece que o setor não deverá resolver estes problemas, pois está adotando o mesmo padrão anterior. 
Quadro 2. Fases do Proálcool e aspectos da orquestração de interesses que elencou o álcool como um importante produto dentro da matriz energética brasileira

\begin{tabular}{|c|c|}
\hline Período & Fatos e características \\
\hline $\begin{array}{c}\text { Até } 1975 \\
\text { Fase anterior }\end{array}$ & $\begin{array}{l}\text { - Em vigor o paradigma subvencionista na agroindústria canavieira. } \\
\text { - Com o IAA ocorre a institucionalização dos arranjos institucionais do setor com os do } \\
\text { Estado. } \\
\text { - Com mecanismos de regulação da atividade produtiva (estabelecimento de quotas de } \\
\text { produção, fixação de preços, concessão de subsídios, etc.), o produtor não precisava, ne- } \\
\text { cessariamente, preocupar-se com alternativas tecnológicas que pudessem reduzir custos. } \\
\text { - A agroindústria canavieira baseia-se na produção de açúcar, o álcool é visto como resíduo. }\end{array}$ \\
\hline $\begin{array}{c}\text { De } 1975 \text { a } 1979 \\
\text { Expansão } \\
\text { moderada }\end{array}$ & $\begin{array}{l}\text { - A } 1^{\text {a }} \text { crise do petróleo: gerou um "gargalo" no processo produtivo, propiciando um } \\
\text { ambiente favorável à produção de substitutos para os derivados do petróleo. } \\
\text { - A crise da agroindústria açucareira favoreceu a orquestração de interesses que levou o } \\
\text { país a optar pelo Proálcool (nessa } 1^{\text {a }} \text { fase fundamentada no álcool anidro). } \\
\text { - } 0 \text { arranjo para viabilizar o Proálcool englobou os empresários das usinas e destilarias, } \\
\text { o Estado, o setor de máquinas e equipamentos e a indústria automobilística. } \\
\text { - Confirmou-se, no Proálcool, o fato do produtor estar novamente sujeito a uma série de } \\
\text { arranjos institucionais patrocinados pelo Estado (paradigma subvencionista). }\end{array}$ \\
\hline $\begin{array}{c}\text { De } 1980 \text { a } 1985 \\
\text { Expansão } \\
\text { acelerada }\end{array}$ & $\begin{array}{l}\text { - } 0 \text { aprofundamento do "gargalo", provocado pela } 2^{\text {a }} \text { crise do petróleo, propiciou um } \\
\text { ambiente favorável para o lançamento do álcool hidratado, enquanto a orquestração } \\
\text { de interesses corroborou esta alternativa como a opção adequada para substituição de } \\
\text { derivados do petróleo. } \\
\text { - A orquestração de interesses foi mais intensa vis-à-vis a primeira fase, sobressaindo as } \\
\text { contribuiçães do Estado no sentido de reafirmar o padrão de busca das empresas dessa } \\
\text { agroindústria, direcionando-a para a produção do álcool hidratado. } \\
\text { - Houve aumento da produção alcooleira nacional, com o surgimento de novas regiões } \\
\text { canavieiras. Também ocorreu um período de preocupação com o desenvolvimento tec- } \\
\text { nológico no setor, caracterizado pela busca de maior eficiência e redução de custos, } \\
\text { embora com a adoção desigual pelas empresas das várias regiões. }\end{array}$ \\
\hline $\begin{array}{c}\text { De } 1986 \text { a } 1995 \\
\text { Desaceleração } \\
\text { e crise }\end{array}$ & $\begin{array}{l}\text { - } 0 \text { "gargalo" oriundo da crise do petróleo desapareceu. } \\
\text { - Houve desagregação de interesses: no âmbito do Estado; na deserção da indústria auto- } \\
\text { mobilística e/ou na falta de interesse do consumidor pelo carro movido exclusivamente } \\
\text { a álcool; e na agroindústria canavieira. } \\
\text { - Com a redução da participação dos investimentos públicos no Proálcool e desequilíbrio no } \\
\text { mercado de álcool, o interesse em produzir e a comprar um veículo a álcool diminuiu. } \\
\text { - Nessa crise setorial algumas usinas/destilarias encerraram suas atividades e/ou foram } \\
\text { incorporadas pelas mais dinâmicas. }\end{array}$ \\
\hline
\end{tabular}




\begin{tabular}{|c|c|}
\hline $\begin{array}{c}\text { A partir de } 1996 \\
\text { Rearranjo sob a } \\
\text { égide da desre- } \\
\text { gulamentação } \\
\text { setorial }\end{array}$ & $\begin{array}{l}\text { - A desregulamentação contribuiu para ampliar a competitividade do álcool. Os produto- } \\
\text { res tiveram que se adaptar ao livre mercado e caminhar sem o subvencionismo outrora } \\
\text { existente. } \\
\text { - Os produtores passaram a desenvolver competências visando aumentar a eficiência } \\
\text { técnica da produção, reformulando a estrutura organizacional das firmas e buscando } \\
\text { maior coordenação setorial - por exemplo, na UNICA em SP e ALCOPAR no PR. } \\
\text { - A CIDE tem contribuído para garantir a competitividade do álcool em relação à gasoli- } \\
\text { na. O aparato institucional de pesquisa tem dado suporte à capacitação tecnológica. } \\
\text { - A legislação, tornando compulsória a adição entre } 20 \% \text { e } 25 \% \text { de álcool na gasolina } \\
\text { consumida internamente, assegura reserva de mercado para o álcool. } \\
\text { - Mudança no mix de produção entre anidro e hidratado. } \\
\text { - A demanda interna do álcool está sendo impulsionada pelo crescimento das vendas de } \\
\text { veículos flexíveis ou bicombustíveis (flex fuel - gasolina e álcool). } \\
\text { - Novos centros de pesquisa agrícola e industrial. }\end{array}$ \\
\hline
\end{tabular}

Fonte: Shikida (1997) e Dados da Pesquisa (2007)

\section{Cadeia do biodiesel}

O Programa Nacional de Produção e Uso de Biodiesel (PNPB) foi elaborado através de uma parceria entre um grupo de trabalho interministerial, instituído por Decreto pelo Presidente da República - encarregado de apresentar estudos sobre a viabilidade de utilização de óleo vegetal - e associações empresariais, como a ANFAVEA e a Associação Brasileira da Indústria de Óleos Vegetais (ABIOVE).

Visando a implantação do PNPB, o Poder Executivo enviou ao Congresso Nacional dois instrumentos legais. O primeiro (Medida Provisória $n^{\circ} 214$ ) dispõe sobre a introdução do biodiesel na matriz energética brasileira, definindo o termo "biodiesel" e conferindo à Agência Nacional do Petróleo (ANP) responsabilidades de regulação, contratação e fiscalização das atividades econômicas integrantes da indústria dos combustíveis renováveis (incluindo o biodiesel). Outro aspecto importante foi não ter definido a obrigatoriedade da adição de biodiesel ao óleo diesel, apenas informando acerca da autorização da mistura de $2 \%$ de biodiesel ao óleo diesel. De fato, a MP 214/04 deixou de trazer instrumentos para incentivar a produção de biodiesel e gerar benefícios sociais a uma parcela significativa da população brasileira, limitandose, basicamente, a estabelecer que a ANP é o órgão regulador das atividades relativas ao biodiesel e a propor uma definição legal para aquele combustível. 
O Projeto de Lei de Conversão (PLV-60, de 2004) foi sancionado pelo Presidente da República e transformado na Lei $\mathrm{n}^{\circ} 11.097$, de 13 de janeiro de 2005, sendo responsável por estabelecer a obrigatoriedade da adição de $5 \%$ de biodiesel em oito anos após a publicação da referida lei, havendo um percentual obrigatório intermediário de $2 \%$ três anos após a publicação da mesma. Ressalte-se que foram vetados os artigos 16 e 17, que criavam linhas de crédito para cultivo de oleaginosas e para a construção de unidades de produção de biodiesel.

Outrossim, a obrigação legal de adição de pelo menos $2 \%$ de biodiesel é justificável dos pontos de vista social, técnico, ambiental e econômico. Mesmo admitindo-se um custo de produção do biodiesel três vezes maior que o óleo diesel de petróleo, o aumento final para o consumidor seria de apenas R $\$ 0,02$ para se ter um “óleo aditivado". Além disso, o principal motivo dessa obrigatoriedade é o avanço do PNPB.

\subsection{Aspectos econômicos da cadeia do biodiesel}

A produção brasileira de biodiesel ainda é incipiente, ou seja, está em estágio embrionário, sendo fortemente baseada em experiências com plantas-piloto. São 10 unidades que tiveram capacidade de produção autorizada pela ANP (que regula o setor de biodiesel).

A Granol, localizada em Campinas (SP) e Anápolis (GO), é a empresa que apresenta a maior capacidade instalada de produção de biodiesel no Centro-Sul a partir de óleos vegetais variados (soja, milho etc.), enquanto a Agropalma, localizada em Belém/PA, se destaca no Norte-Nordeste, produzindo biodiesel a partir dos resíduos do processo industrial de refino do óleo de dendê, utilizando o etanol como reagente. Assim, percebe-se que a primeira está estruturada na produção em grande escala e a segunda na pequena produção (extrativista).

A Brasil Biodiesel (Floriano/PI) beneficiará cerca de 25 mil famílias, em uma área total de 50 mil hectares no Nordeste. Estas famílias assinaram um contrato com a empresa para a venda da produção de mamona por 10 anos. Em troca, a empresa oferecerá toda a infra-estrutura para viabilizar o cultivo da oleaginosa como transporte, moradia, lazer e cultura.

Dentre as empresas que aguardam autorização da ANP está uma planta da Petrobrás no município de Guamaré (Rio Grande do Norte), 
com tecnologia desenvolvida pelo seu próprio centro de pesquisas. Essa planta deverá ser a primeira experiência brasileira em escala comercial de produção de biodiesel de mamona utilizando o etanol como reagente.

O Programa pretende instalar, ao todo, 24 refinarias de biodiesel nas regiões Norte, Nordeste e Centro-Oeste. Levantamentos do Ministério da Agricultura, Pecuária e Abastecimento (MAPA) indicam que na safra 04/05 84 mil hectares foram cultivados com oleaginosas por agricultores familiares para a produção de biodiesel, dos quais 59 mil estão localizados na região Nordeste (PAULILLO et al., 2006).

Outros investimentos estão em andamento no setor, como o da fabricante de óleos vegetais Biobrás Eco Óleo, que está investindo cerca de US\$11,8 milhões na construção de quatro novas unidades industriais, que devem produzir 75 milhões de litros de biodiesel por ano. Uma das fábricas será instalada no Rio de Janeiro (na cidade de Quissamã), outra no sul de Minas Gerais e duas em Goiás. A Expoglobe Internacional é outro exemplo, com 5 milhões de dólares em investimento na instalação de uma planta em Campo Largo (PR), que deve entrar em operação até o final de 2006 e a francesa Dagris, que está investindo US\$121,4 milhões na instalação de duas usinas (BA), utilizando sementes de algodão e girassol.

De acordo com o Ministério das Minas e Energia, cerca de $800 \mathrm{mi}$ lhões de litros de biodiesel devem ser produzidos no Brasil por ano, o que contribuiria para reduzir as importações de diesel de petróleo ${ }^{3}$, estimadas em 4 bilhões de litros em 2005 (cerca de 20\% do óleo diesel consumido no país é importado). Considerando um consumo de óleo diesel de 38 bilhões de litros por ano, a adição de $2 \%$ de biodiesel (B2) regulamentada por lei deve gerar uma demanda de 760 milhões de litros/ano (F.O. LICHT, 2005). Até meados de 2005, o biodiesel podia ser encontrado em apenas quatro postos de Belo Horizonte e dois em São Paulo, sendo a previsão de expandir para cerca de 70 até o final de 2006 (PAULILLO et al., 2006).

Para o MAPA, a área plantada para atender ao percentual de mistura de $2 \%$ de biodiesel ao diesel de petróleo (cerca de 760 milhões

${ }^{3}$ O Brasil ainda importa parcela de diesel, mesmo após ter atingido a auto-suficiência na produção de petróleo, porque o diesel extraído aqui é de difícil refino em face da tecnologia nacional. 
de litros/ano) é estimada em 1,5 milhão de hectares, o que equivale a $1 \%$ dos 150 milhões de hectares plantados e disponíveis para a agricultura no Brasil.

A Escola Superior de Agricultura Luiz de Queiroz - ESALQ/USP é a entidade que abriga o Pólo Nacional de Biocombustíveis no Brasil, que tem a função de analisar os sistemas de produção de variedades que podem ser usadas na fabricação de combustíveis renováveis, como o biodiesel. Segundo dados da ABIOVE, apenas o excedente do óleo de soja já supera a quantidade necessária para a adição de $2 \%$ de biodiesel no combustível mais consumido no país (PAULILLO et al., 2006).

Em cada estado e região do Brasil está sendo avaliado pelo MAPA o desenvolvimento das cadeias produtivas de diferentes óleos vegetais. Para a região Norte: dendê, babaçu, soja e gordura animal; para o Nordeste: babaçu, soja, mamona, dendê, algodão, coco, gordura animal e óleo de peixe; para o Sul: soja, colza, girassol, algodão, gordura animal e óleos de peixes; e, para o Sudeste: soja, mamona, algodão, girassol, gordura animal e óleos de peixes.

O investimento na produção de biodiesel deve chegar a 515 milhões de dólares em 2008, quando deverão estar em produção cerca de 800 milhões de litros do combustível, volume necessário para a mistura de $2 \%$. Em 2013, a cifra deve aumentar para 1,5 bilhão de dólares, com 2 bilhões de litros no mercado nacional. A produção de biodiesel permitirá a redução da importação de diesel, gerando uma economia anual de 1,2 bilhão de dólares.

Assim, percebe-se que o mercado do biodiesel (juntamente com o do álcool) vem crescendo nos últimos anos em função das preocupações de grupos organizados e dos governos federais com o meio ambiente e a redução da dependência do petróleo importado. Em 2004, alguns países lançaram programas de incentivo à produção e consumo de biocombustíveis. Como nos principais países produtores de biodiesel a produção é suficiente para cobrir a demanda interna, o comércio mundial destes produtos ainda é insignificante.

O principal produtor e consumidor de biodiesel está na União Européia, que vem fabricando o produto em larga escala desde 1992. Apesar da implementação do Programa do bioetanol, o biodiesel continua dominando a cena dos combustíveis alternativos na Europa. 
Em resposta aos incentivos por parte das instituições européias (subsídios às plantações de produtos alimentícios em áreas até então não utilizadas e isenção de $90 \%$ dos impostos), cerca de 40 usinas foram montadas em diversos países do bloco, gerando uma capacidade total de produção de 2.582 milhões de litros em 2004. A produção efetiva nos principais países produtores atingiu 2.222 milhões de litros, o que representa um crescimento de $35 \%$ em relação ao ano anterior (PAULILLO et al., 2006).

Aproximadamente a metade da capacidade produtiva de biodiesel europeu está na Alemanha (1.250 milhões de litros), que é o maior produtor mundial do biocombustível, utilizando como principal matériaprima a canola. Em 2004, foram produzidos 1.190 milhões de litros de biodiesel no país, contra 827 milhões em 2003 e 632 milhões em 2002. Para 2005, a perspectiva é de que a produção alemã fique entre 1.600 e 1.800 milhões de litros, em função da instalação de novas plantas industriais. O governo alemão concede subsídios de 47 euros para cada 100 litros de biodiesel (F. O. LICHT, 2005).

Os Estados Unidos estão em quarto lugar na produção de biodiesel em 2004, com 113 milhões de litros, seguidos pela Dinamarca (80 milhões de litros), Áustria (65 milhões de litros) e Espanha (15 milhões de litros). Nos Estados Unidos, o interesse pela produção do biodiesel vem crescendo em decorrência de vários aspectos: das leis federais e estaduais que autorizam o uso do biodiesel como combustível ou aditivo na proporção de $20 \%$, dos incentivos tarifários e creditícios concedidos pelo governo aos fabricantes do produto e da necessidade de dar vazão aos estoques extras de óleo de soja em vários estados americanos. Novamente o uso de combustíveis renováveis ajuda a equalizar o excesso de oferta agrícola para alimentação animal e humana e conciliar os interesses dos ambientalistas e agricultores.

O Quadro 3 resume o estágio em que se encontram os programas de biodiesel em alguns países. Percebe-se que existem várias fontes de matérias-primas e que a questão ambiental é um fator de suporte importante para as pesquisas e programas de biocombustíveis. 
Quadro 3. Estágio atual dos programas de biodiesel no mundo

\begin{tabular}{|c|c|}
\hline País & Estágio atual \\
\hline $\begin{array}{l}\text { Estados } \\
\text { Unidos }\end{array}$ & $\begin{array}{l}\text { 2\% de mistura em Minnesotta, autorização de } 20 \% \text { no país, mas com possibilidades de tornar } \\
\text { obrigatória. }\end{array}$ \\
\hline Brasil & $\begin{array}{l}\text { Em 2004, o governo autorizou 2\% de mistura de óleos vegetais ao óleo diesel. Entretanto, só a } \\
\text { partir de } 2008 \text { este percentual será obrigatório, aumentando para 5\% em } 2013 \text {. }\end{array}$ \\
\hline Alemanha & $\begin{array}{l}\text { Lei exige pelo menos } 5 \% \text { de mistura, dando permissão para usar o combustível em qualquer } \\
\text { proporção. }\end{array}$ \\
\hline França & $\begin{array}{l}\text { 5\% de mistura, devendo aumentar para 8\%. Os ônibus urbanos utilizam mistura com até 30\% } \\
\text { de biodiesel. }\end{array}$ \\
\hline Canadá & $\begin{array}{l}\text { Programa em desenvolvimento. Algumas companhias de ônibus estão fazendo testes com } \\
\text { biodiesel importado com uma mistura de } 20 \% \text {. } 0 \text { governo canadense concedeu isenção fiscal } \\
\text { de } 4 \% \text { sobre a produção e uso do biocombustivel e estabeleceu uma meta de produção de } 500 \\
\text { milhões de litros/ano até } 2010 \text {. }\end{array}$ \\
\hline Argentina & $\begin{array}{l}0 \text { governo iniciou um programa em 2001, oferecendo vantagens fiscais para a produção do } \\
\text { biocombustível. Atualmente, há } 7 \text { unidades de produção de biodiesel no país, mas apenas } 1 \\
\text { fábrica está produzindo em baixa escala. }\end{array}$ \\
\hline Japão & $\begin{array}{l}\text { Empresas locais produzem biodiesel a partir da reciclagem do óleo de cozinha usado (5 mil } \\
\text { litros/dia). } 0 \text { produto é utilizado nos veículos das próprias empresas, nos veículos governamen- } \\
\text { tais e em caminhões de lixo de algumas cidades japonesas, numa proporção de mistura de } 20 \% \text {. } \\
\text { Falta regulamentar lei sobre o assunto, sendo que o país está considerando a possibilidade de } \\
\text { adição de } 1 \% \text { em 2006, com possibilidade de aumentar para } 5 \% \text { e } 10 \% \text {, posteriormente. Com } \\
\text { uma mistura de } 5 \% \text { (B5), a demanda gerada será de } 2,5 \text { bilhões de litros de biodiesel/ano. }\end{array}$ \\
\hline Malásia & $\begin{array}{l}\text { Programa para a produção do biodiesel está em fase de implementação, utilizando como prin- } \\
\text { cipal matéria-prima o óleo de palma de dendê (maior produtor mundial desse produto). A } \\
\text { construção da primeira usina deve terminar em } 2008 \text { (com capacidade instalada de } 5 \text { mil tone- } \\
\text { ladas/mês). O país visa a exportação do produto, principalmente para a Europa. }\end{array}$ \\
\hline Austrália & $\begin{array}{l}\text { Já possui algumas usinas de biodiesel produzindo em larga escala (a partir do óleo de cozinha } \\
\text { reciclado), com uma capacidade de produção de } 20 \text { milhões de litros/ano. Pretende iniciar a } \\
\text { produção do etanol para biodiesel. }\end{array}$ \\
\hline Tailândia & $\begin{array}{l}\text { Possui programa aprovado para promover o uso do biodiesel no diesel de petróleo nos próximos } \\
\text { sete anos. A porcentagem de mistura deve ser de } 10 \% \text {, gerando uma demanda interna de } 3,1 \\
\text { bilhões de litros por ano. A matéria-prima principal é o óleo de palma. }\end{array}$ \\
\hline Índia & $\begin{array}{l}\text { Está em construção a primeira unidade de produção de biodiesel. Para a elaboração do pro- } \\
\text { grama nacional de biodiesel, vem fazendo parcerias com a Alemanha na questão tecnológica. }\end{array}$ \\
\hline $\begin{array}{c}\text { Coréia do } \\
\text { Sul }\end{array}$ & $\begin{array}{l}\text { Duas pequenas fábricas de biodiesel estão em operação no país, somando uma capacidade de } \\
\text { produção de } 8 \text { mil toneladas/ano. Percentual de mistura é de } 20 \% \text { (opcional). }\end{array}$ \\
\hline Taiwan & $\begin{array}{l}\text { Possui lei aprovada para adição de } 20 \% \text { de biodiesel no diesel de petróleo desde o ano } 2000 . \\
\text { Em } 2004 \text { foi construída a primeira fábrica, produzindo em baixa escala a partir do óleo de } \\
\text { cozinha reciclado. }\end{array}$ \\
\hline Filipinas & $\begin{array}{l}0 \text { país possui três plantas industriais de biodiesel, com produção de } 33 \text { milhões de litros. Este } \\
\text { volume deve aumentar para } 150 \text { milhões em 2007, com pretensões de exportar o produto para } \\
\text { o Japão. }\end{array}$ \\
\hline
\end{tabular}

Fonte: Paulillo et al. (2006). 


\subsection{Orquestração de interesses e paradigma}

O caso do biodiesel trata-se, conforme já salientado, de um agroenergético ainda em estágio embrionário no Brasil, sendo que apenas quatro unidades industriais estão em funcionamento. Alguns projetos estão em análise por instituições de fomento, mas as indefinições sobre o PNPB estão estorvando a liberação dos recursos financeiros.

Contudo, são vários os estudos de viabilidade técnica que estão em andamento no país, a fim de descobrir quais são as oleaginosas mais eficientes para a produção em larga escala. Estima-se que, quando a Lei Federal (Lei ${ }^{\circ}$. 11.097, de 13/01/2005, que estabelece a obrigatoriedade da adição, exigindo um percentual de $2 \%$ de mistura de biodiesel em cada litro do diesel, a partir de 2008, com elevação para 5\% em 2013) entrar em funcionamento, a demanda seja de 760 milhões de litros/ano.

Novamente se verifica, agora em termos de PNPB, que os agentes integrantes dessa ordem possuem certo grau de interesses, sendo que os conflitos estão na produção agrícola e no âmbito regional. Os incentivos à produção de biodiesel de mamona são conflitantes com os interesses das grandes esmagadoras de soja.

Mutatis mutandis, para os produtores de óleo vegetal trata-se de estimular/diversificar sua produção - no caso específico da soja, trata-se de criar um novo mercado diante da crise de excesso de oferta desta commodity. Para o Estado, assim como no Proálcool, seus interesses resumemse na: economia de divisas; diminuição das desigualdades regionais de renda; crescimento da renda interna; geração de empregos; e expansão da produção de bens de capital; além de atuar como intermediador num possível conflito de interesses entre os agentes (cumpre salientar que esta intermediação do Estado se faz agora em um contexto diferenciado dos idos das décadas de 1970 e 1980, período em que foi implementado o Proálcool). ${ }^{4}$ Para o setor de máquinas e equipamentos (indústria de bens

${ }^{4}$ Nos anos 70 existia um regime de câmbio distinto deste atual, sendo a escassez de divisas notória. Considerando o regime de câmbio flutuante e melhoria do nível de divisas, vigentes atualmente, salvo as exceções de externalidades e vantagens comparativas dinâmicas, a substituição de importações no país deve ser comandada pela taxa de câmbio e, não, pela escolha (até certo ponto, arbitrária) dos produtos a serem favorecidos/protegidos. A grande diferença dos momentos de implantação do Proálcool com o PNPB está no perfil do Estado, isto é, na época do lançamento do Proálcool existia uma forte ditadura, 
de capital), o advento do biodiesel também permite vislumbrar um quadro de crescimento de sua atividade. Para a ANFAVEA, tudo que propiciar o aumento da frota é bem vindo. Outrossim, além de ser uma tecnologia limpa, o emprego do biodiesel no óleo diesel de petróleo polui menos o meio ambiente, sendo bandeira de movimentos ecológicos, assim como foi no Proálcool. Por outro lado, como o paradigma tecnológico ainda não foi definido, não se pode antecipar se o biodiesel será alvo de críticas ambientalistas como é o álcool atualmente (queimadas etc.).

As principais matérias-primas para a produção nacional do biodiesel, conforme já salientado, são: soja, milho, girassol, amendoim, algodão, canola, mamona, babaçu, palma (dendê) e macaúba, entre outras. O combustível também pode ser obtido a partir de óleos residuais e de gorduras animais. Embora o Brasil possua grande diversidade de insumos agrícolas para a produção de óleos vegetais e, conseqüentemente, de biodiesel, muitas culturas ainda têm caráter extrativista, não havendo plantios comerciais que permitam avaliar suas reais potencialidades e outras ainda são cultivadas com baixo índice de tecnologia, fruto do desinteresse na $P \& D$ de variedades e de equipamentos para mecanização.

Destarte, a soja (que representa $90 \%$ da produção brasileira de óleos vegetais), o dendê, o coco, o girassol e a mamona, são as principais opções. A Tabela 1 apresenta algumas características de culturas oleaginosas com potencial de uso para fins energéticos.

Tabela 1. Características de culturas oleaginosas no Brasil

\begin{tabular}{l|c|c|c|c}
\hline \multicolumn{1}{c|}{ Espécie } & $\begin{array}{c}\text { Origem do } \\
\text { Óleo }\end{array}$ & $\begin{array}{c}\text { Teor de Óleo } \\
\text { (\%) }\end{array}$ & $\begin{array}{c}\text { Meses de Colheita/ } \\
\text { ano }\end{array}$ & $\begin{array}{c}\text { Rendimento } \\
\text { (ton. óleo/ha) }\end{array}$ \\
\hline Dendê/Palma & Amêndoa & 22 & 12 & $3,0-6,0$ \\
Coco & Fruto & $55-60$ & 12 & $1,3-1,9$ \\
Babaçu & Amêndoa & 66 & 12 & $0,1-0,3$ \\
Girassol & Grão & $38-48$ & 3 & $0,5-1,9$ \\
Colza/Canola & Grão & $40-48$ & 3 & $0,5-0,9$ \\
Mamona & Grão & $45-50$ & 3 & $0,5-0,9$ \\
Amendoim & Grão & $40-43$ & 3 & $0,6-0,8$ \\
Soja & Grão & 18 & 3 & $0,2-0,4$ \\
Algodão & Grão & 15 & 3 & $0,1-0,2$ \\
\hline
\end{tabular}

Fonte: Paulillo et al. (2006).

sendo os desígnios do Estado pouco contestados. Atualmente, o Brasil vive um regime democrático, e o mercado vem assumindo com mais freqüência a direção dos processos de decisões nas articulações corporativas. 
No caso do biodiesel, a competitividade brasileira esbarra nos elevados custos de produção, tendo em vista que a tecnologia de processamento ainda é imatura. Pela sua capacidade produtiva na região Nordeste (150 mil hectares na Bahia, com produtividade de 3 toneladas/ha), constituindo alternativa para o estabelecimento da agricultura familiar, a mamona foi pensada como o carro chefe na fase inicial do PNPB. Contudo, embora a região Nordeste tenha aptidão agronômica para o cultivo e expansão desta matéria-prima, as práticas e tecnologias de manejo dessa cultura são inadequadas, tornando a produção de biodiesel a partir desta oleaginosa a menos competitiva (US\$ 1,0/litro - sem impostos). Além disso, o óleo de mamona possui preço elevado no mercado internacional (cerca de US\$1.000,00/tonelada), em função dos diversos usos que possui na indústria química. Para que seu preço se reduza ao patamar dos demais óleos vegetais empregados na produção de biodiesel, deveria haver uma elevação na oferta desta matéria-prima.

Em relação ao babaçu, embora seja cultivado em uma área de 18 milhões de hectares no Maranhão, o custo de extração do vegetal é elevado, em função da sua produção ainda ser baseada no extrativismo, com baixo padrão de organização (MAPA, 2005). Pesquisas na ESALQUSP mostram que há potencial em outros produtos extrativos da floresta amazônica, mas novos testes precisam ser feitos para analisar o real teor de óleo e os custos de produção.

No caso da soja, mesmo com potencial para oferecer todo o óleo necessário para uma mistura B5 no Brasil, tal matéria-prima apresenta restrições de natureza econômica, tendo em vista o elevado custo de produção do óleo e o custo de oportunidade da opção de exportar o grão, o farelo ou o próprio óleo para o mercado internacional. Estudos da ABIOVE indicam que a produção do biodiesel só é viável a uma cotação do óleo de soja no mercado externo abaixo de US\$480,00/toneladas $^{5}$. Além disso, na principal região produtora de soja (Centro-Sul), os

${ }^{5}$ A produção a partir de soja refinada custa US\$ 0,50/litro sem impostos. Se for utilizada a soja não refinada, o valor cai para US\$ 0,38 por litro, entretanto, o refino da soja custa entre US\$ 120 e US $\$ 150$ por tonelada. A produção a partir da mamona custa US\$ 1/litro. Ademais, novas condições de preços do óleo de soja estão se configurando, por exemplo, na Bolsa de Chicago a cotação (maio/2007) para o óleo de soja bruto e refinado remonta ao patamar de US $\$ 758,82 /$ tonelada. Uma discussão pertinente sobre este ponto está em Paulillo et al. (2006). 
benefícios fiscais são menores, afetando a competitividade da cultura destinada para a fabricação de biodiesel. Esta preocupação quanto à competitividade da soja tem levado algumas empresas que aguardam autorização da ANP a analisar a viabilidade do emprego de matériasprimas alternativas para a produção do biodiesel, como o nabo forrageiro, o girassol, a borra do processo siderúrgico, a borra do processo de refino do óleo de soja e o sebo bovino ${ }^{6}$. O problema é que tais matériasprimas não têm mercados sólidos, o que implica no aumento dos riscos quanto ao seu fornecimento (MAPA, 2005).

A cultura com melhor desempenho na produção do biocombustível é o dendê, com o qual é possível obter 6 mil litros por hectare cultivado (PAULILLO et al., 2006), porém sua produção também se dá com base no extrativismo, com práticas e tecnologia de manejo ineficientes. Pesquisas são necessárias para implantar grandes cultivos comerciais.

Numa análise comparativa, em 1975 também havia várias alternativas para a produção de derivados do petróleo, como o próprio óleo vegetal, o álcool derivado da cana ou da mandioca (neste caso procurando priorizar a agricultura familiar) e o carvão. Os interesses organizados do setor com as estruturas de decisão do Estado alavancaram o álcool anidro como aditivo à gasolina, sobrepujando outras alternativas energéticas, mas, com baixo poder de articulação de interesses. O álcool hidratado surgiu como substituto da gasolina nos anos 80. No início havia muitos problemas técnicos com os motores à álcool, mas que foram sendo resolvidos com a participação de todos os agentes e a evolução das pesquisas.

Neste novo contexto o que deverá prevalecer? A articulação de interesses e/ou o maior poder de capacitação tecnológica das atividades fornecedoras de biodiesel? Qual será a atividade que de fato alavancará o PNPB, considerando que o Estado implementará este Programa nos próximos anos? Respeitando as peculiaridades técnicas e regionais de produção (babaçu no Norte-Nordeste, e a soja no Centro-Sul, por exemplo), numa eventual larga escala de produção, a tendência é de incorporação de tecnologias altamente redutoras de custos de produção às

${ }^{6}$ Relato de empresários do setor dão conta de que, atualmente, a única matéria-prima que permite a produção do biodiesel a custos competitivos com o diesel de petróleo é o sebo bovino. O Bertin, um dos maiores frigoríficos nacionais, está planejando investir neste segmento. 
atividades não extrativistas. Será possível conciliar todos os interesses em jogo? Tentar-se-á responder a esta indagação adiante.

A inserção da agricultura familiar no PNPB, em sendo intento do Estado, demandará uma articulação maior para sobreviver em um contexto mais concorrencial. Esta preocupação se fundamenta no fato da produção e cultivo de matérias-primas destinadas à produção de biodiesel poderem ajudar a criar milhares de novos empregos na agricultura familiar, principalmente nas regiões mais pobres do Brasil, além da possibilidade de reduzir a dependência brasileira das importações de petróleo. Estudos desenvolvidos pelo Ministério do Desenvolvimento Agrário, Ministério da Agricultura, Pecuária e Abastecimento, Ministério da Integração Nacional e Ministério das Cidades mostram que, a cada $1 \%$ de participação da agricultura familiar no mercado de biodiesel do país, baseado no uso do B5 (5\% de biodiesel no diesel de petróleo), seria possível gerar cerca de 45 mil empregos no campo, a um custo médio de cerca de $\mathrm{R} \$ 4.900,00$ por emprego. Cada $\mathrm{R} \$ 1,00$ aplicado na agricultura familiar gera $\mathrm{R} \$ 2,13$ adicionais na renda bruta anual, o que significa que a renda familiar dobraria com a participação no mercado do biodiesel. Estas estimativas justificam a conotação social dada ao PNPB por parte do governo (PAULILLO et al., 2006).

Vale citar que até o final de 2005, cerca de 20 mil unidades familiares produtoras de oleaginosas das regiões Norte-Nordeste estavam inseridas na cadeia do biodiesel, sendo a previsão de atingir 100 mil até o final de 2006 e 250 mil até 2007.

Contudo, o PNPB não se iniciou como um "factóide" para a agricultura familiar (no Norte-Nordeste), ou para a crise agrícola de 2005/2006, por conta dos preços da soja (no Centro-Sul). O que houve foi uma junção de fatores favoráveis para a criação do PNPB, assim como houve para o Proálcool. No caso do biodiesel, o marco institucional vigente também pode ser considerado favorável para desenvolver o mercado do produto, ainda em gestação. A legislação tornando compulsória a mistura de $2 \%$ do biocombustível no óleo diesel de petróleo, a partir de 2008, foi o primeiro passo dado. Depois vieram os incentivos do governo para desenvolver pesquisas quanto à utilização de matérias-primas alternativas empregadas na produção do biodiesel, assim como houve no Proálcool. Observa-se, portanto, que esta orquestração de interesses está 
sendo capitaneada pelo Estado, via paradigma subvencionista, como no início do Proálcool em 1975. Por exemplo, para garantir a oferta do aditivo, o governo está oferecendo incentivos para o cultivo em massa de plantas produtoras de óleo. No caso da produção a partir da agricultura familiar, há isenção fiscal de até $68 \%$ no pagamento do Programa de Integração Social (PIS)/Contribuição para Financiamento da Seguridade Social (COFINS), independentemente da localização geográfica e das oleaginosas cultivadas. Para a cultura da mamona e dendê, no Norte e Nordeste, há isenção total destes impostos. O agricultor não familiar, por outro lado, terá até $32 \%$ de isenção destes tributos. Em qualquer condição, o biodiesel estará isento do pagamento da CIDE. A isenção fiscal se dará através da concessão do Selo Combustível Social, que também habilitará os produtores a ofertarem seus produtos nos leilões que se iniciaram a partir de janeiro de 2006 (PAULILLO et al., 2006).

Além da isenção fiscal, o Banco Nacional de Desenvolvimento Econômico e Social (BNDES) tem aprovado empréstimos para financiar até $80 \%$ dos investimentos na montagem de plantas industriais para fabricar biodiesel.

Este modelo de paradigma subvencionista não é exclusivo do biodiesel. Apenas como exemplo, no caso do Proálcool, para os investimentos industriais foram instituídos, para os produtores do Norte/Nordeste, taxas de juros de $15 \%$ ao ano e, para os do Centro-Sul, $17 \%$ ao ano, tudo sem correção monetária. Este financiamento envolvia 100\% do investimento (a partir de 1977 a parcela financiada foi reduzida para $90 \%$ para o Norte/Nordeste e $80 \%$ para o Centro-Sul), sendo que o prazo de amortização era de 12 anos, sendo três anos de carência. Os investimentos agrícolas ainda pagavam uma taxa de $7 \%$ ao ano (à época, metade da taxa de crédito rural), tendo os mesmos prazos que o crédito industrial para investimentos fixos e de um a três anos para o custeio agrícola (MOREIRA, 1989; SHIKIDA, 1997).

Esta realidade de subvenção não é especialidade apenas nacional; na União Européia, onde se encontram os maiores produtores mundiais de biodiesel (Alemanha, França e Itália), o litro do combustível custa entre 50 centavos de euro e 80 centavos de euro, dependendo do tipo de matéria-prima, sendo que a produção de combustíveis fósseis sai pela metade do preço. Mesmo considerando os incentivos dos governos eu- 
ropeus, a pequena margem de lucro acaba desestimulando a produção em algumas unidades produtivas (PAULILLO et al., 2006).

Este modelo subvencionista está atrelado ao fato das atuais tecnologias de fabricação de bioenergia só serem efetivamente competitivas se o barril de petróleo atingir a marca de US\$ 60 o barril indefinidamente. Assim, é necessário que o PNPB leve em consideração outros aspectos, como o ambiental e o social e não apenas os preços externos do petróleo.

Cumpre dizer que alguns agentes do setor alegam que a política de preços da Petrobrás vem prejudicando a viabilidade dos investimentos em energia renovável. $\mathrm{O}$ fato de a estatal segurar o preço do óleo diesel, em plena época de alta nos preços do petróleo no mercado internacional, como forma de controlar a inflação, tira a competitividade do biodiesel.

No Brasil, uma das principais vantagens competitivas em relação a outros países é a perspectiva de incorporação de áreas à agricultura de energia, sem "competição" com a agricultura de alimentos, além da possibilidade de múltiplos cultivos dentro do mesmo ano. No caso da União Européia, esta questão constitui-se num fator crítico, tendo em vista a pequena área disponível para o plantio de matérias-primas que podem ser utilizadas na produção de biocombustíveis. Dado o crescimento da população e do consumo de alimentos (incluindo-se a carne), a expansão da produção nestes países pode ficar comprometida.

Para o biodiesel, o atual nível de produção constitui um grande desafio para o cumprimento das metas estabelecidas no âmbito do PNPB, que necessitará de, aproximadamente, 760 milhões de litros em sua fase inicial, para a mistura B2 no óleo de petróleo (considerando um consumo de 38 bilhões de litros de petróleo/ano e o percentual de mistura de $2 \%$ de biodiesel, resulta numa demanda de 760 milhões de litros). A capacidade produtiva atual de 176 milhões de litros/ano é capaz de atender apenas $23 \%$ da demanda, porém, com a aprovação das usinas cuja solicitação tramita na ANP, a capacidade instalada é suficiente para atender a demanda prevista a partir de 2006 (MAPA, 2005). Estima-se que esta capacidade terá que ser triplicada a partir de 2013, com a necessidade de adição de $5 \%$ de biodiesel ao diesel de petróleo.

As previsões do MAPA também indicam que, até 2015, toda a produção brasileira de biodiesel deve ser absorvida pelo mercado interno, não havendo exportações do produto. A maior parte do biocombustível 
deve ser produzida pela rota de transesterificação etanólica (cerca de $90 \%$ ), sendo o restante por craqueamento térmico (transformação por ruptura de moléculas grandes em moléculas menores; utilizado para transformar óleos pesados em derivados mais leves). Neste caso, devese gerar uma demanda de etanol de 6 bilhões de litros entre 2030 e 2035, evidenciando o potencial de integração com a cadeia do álcool.

A produção estimada de biodiesel será ofertada por pequenas, médias e grandes usinas, sendo que, no último caso (de grande porte), o setor deverá contar com 900 unidades com capacidade produtiva em torno de 100 toneladas ano.

No entanto, para que estas expectativas de produção sejam efetivadas, vários fatores devem ser considerados. Em primeiro lugar, as regras definidas em relação aos percentuais de mistura obrigatória de biodiesel no óleo de petróleo (inicialmente B2 e B5 a partir de 2013) têm que ser cumpridas, de modo a garantir mercado para o produto. Por outro lado, os projetos de construção de usinas de processamento de biodiesel, que ainda estão em andamento, devem ser concretizados, garantindo capacidade instalada para atender as metas de consumo. Um obstáculo a ser transposto para concretizar a produção de biodiesel em larga escala diz respeito à questão tecnológica, que exigirá elevados investimentos nos próximos anos. Há necessidade de investimentos em P\&D para promover o adensamento energético das espécies oleaginosas (aumentando a produtividade), evitando a pressão por incorporação de novas áreas agrícolas e de investimentos na implantação de tecnologias modernas de produção, de forma a garantir a competitividade do produto, não encarecendo o preço final do óleo diesel consumido internamente. Neste caso, o aparato de P\&D terá a sua importância no processo evolutivo do Programa, e desse desenvolvimento dependerá o futuro de um provável momento de paradigma tecnológico no caso do biodiesel.

A solução da questão tecnológica, aliada ao elevado preço do petróleo, às isenções fiscais e à garantia de mercado cativo (assegurada pela legislação aprovada), deve alavancar um fluxo contínuo de investimentos nos próximos anos, que permitirá alcançar as metas de produção do biodiesel estimadas pelo governo. Estes aspectos contribuiriam para dar sustentabilidade à cadeia do biodiesel. Aqui cumpre citar que as rodadas de orquestração de interesses irão definindo gradualmente as 
Quadro 4. Estágio atual, perspectivas e orquestração de interesses para o PNPB

\begin{tabular}{|c|c|}
\hline \multicolumn{2}{|r|}{ Estágio atual e perspectivas para o biodiesel no Brasil } \\
\hline Estágio atual & $\begin{array}{ll}\text { - } & \text { Unidades de produção, em pequena escala, localizadas no Norte e Nordeste. } \\
\text { - } & \text { QuatropostosemBeloHorizonteedoisemSãoPaulojácomercializamobiodiesel. }\end{array}$ \\
\hline $\begin{array}{l}\text { Produção } \\
\text { estimada }\end{array}$ & 800 milhões de litros/ano. \\
\hline \begin{tabular}{|c|} 
Área destinada \\
à produção \\
agrícola
\end{tabular} & 1,5 milhão de hectares. \\
\hline $\begin{array}{l}\text { Demanda } \\
\text { estimada }\end{array}$ & 760 milhões de litros/ano. \\
\hline $\begin{array}{c}\text { Orquestração de } \\
\text { interesses }\end{array}$ & $\begin{array}{l}\text { - Paraosprodutoresdeóleovegetaltrata-sedeestimular/diversificarsuaprodução. } \\
\text { - } \quad \text { ParaoEstado,seusinteressesresumem-sena:economiadedivisas;diminuiçãodas } \\
\text { desigualdades regionais de renda; crescimento da renda interna; geração de empregos; } \\
\text { e expansão da produção de bens de capital; além de atuar como intermediador entre os } \\
\text { agentes. Definidor da legislação do setor (adição de } 2 \% \text { no óleo diesel a partir de } 2008 \\
\text { e elevação para 5\% a partir de 2013). } \\
\text { - Paraosetordemáquinaseequipamentos:comobiodieselsepermitevislumbrarum } \\
\text { crescimento da atividade. } \\
\text { - } \quad \text { Para a ANFAVEA: tudo que propiciar o aumento da frota é bem vindo. } \\
\text { - } \quad \text { emprego do biodiesel no óleo diesel de petróleo polui menos o meio ambiente, } \\
\text { sendo bandeira de movimentos ecológicos. }\end{array}$ \\
\hline $\begin{array}{c}\text { Paradigma } \\
\text { subvencionista }\end{array}$ & $\begin{array}{l}\text { - Investimentosprevistos:cercadeUS\$515milhõesaté2008eUS\$1,5biaté2013 (com } \\
\text { forte participação do Estado). } \\
\text { - } \quad \text { Ogoverno está oferecendoincentivos para o cultivo deplantas produtoras deóleo } \\
\text { (isenção fiscal de até } 68 \% \text { no pagamento do PIS/COFINS). Para a cultura da mamona e } \\
\text { dendê, no Norte e Nordeste, há isenção total destes impostos. } \\
\text { - } \quad \text { agricultor não familiar terá até } 32 \% \text { de isenção destes tributos. } \\
\text { - } \quad \text { Em qualquer condição, o biodiesel estará isento do pagamento da CIDE. } \\
\text { - } \quad \text { OBNDEStemaprovadoempréstimosparafinanciaraté80\% dosinvestimentosna } \\
\text { montagem de plantas industriais para fabricar biodiesel. }\end{array}$ \\
\hline Perspectivas & $\begin{array}{l}\text { - Dasprincipaismatérias-primasparaaproduçãodobiodiesel[soja,milho,girassol, } \\
\text { amendoim, algodão, canola, mamona, babaçu, palma (dendê) e macaúba, óleos re- } \\
\text { siduais e de gorduras animais, etc.], não há ainda um produto que se destaque na } \\
\text { tecnologia de processamento. } \\
\text { - Peculiaridadesregionaispoderãodemarcarcenáriosdistintosdeutilizaçãodematéria- } \\
\text { prima (babaçu no Norte-Nordeste, e a soja no Centro-Sul, por exemplo). } \\
\text { - Incentivoàescalacomercialepreocupaçãoparainserçãodaagriculturafamiliar.Ar- } \\
\text { ranjos institucionais deverão ser feitos de modo a administrar esta convivência. } \\
\text { - HánecessidadedeinvestimentosemP\&D,deformaagarantircompetitividadedo } \\
\text { produto. }\end{array}$ \\
\hline
\end{tabular}

Fonte: Dados da Pesquisa (2007) 
linhas mestres do PNPB, em que a satisfação dos interesses de seus agentes poderá ser alcançada pelo ajuste mútuo e pelas interações repetidas. Isto, no entanto, não será linear, pois contratempos e desajustes poderão ocorrer. Assim, a função de articulação dos interesses, capitaneada pelo Estado, será importante para o PNPB.

Cabe salientar aspectos ligados à localização das unidades processadoras e o mercado consumidor de biodiesel. Na versão atual os incentivos são para o Nordeste e o consumo está centralizado no Sul, portanto, existem problemas logísticos para serem equacionados.

Considerando que o PNPB está em fase de implementação, mostrando, inclusive, falta de definição da política oficial de preços do produto por parte do governo federal, o Quadro 4 resume as principais informações quanto ao estágio atual e as perspectivas do PNPB.

\section{Considerações finais}

O objetivo deste trabalho foi o de analisar, à guisa do referencial de redes políticas neocorporativistas, duas importantes cadeias de agroenergia brasileira: a do álcool e a do biodiesel.

Como corolário, é muito provável que a assinatura do Protocolo de Kyoto (que exige a redução das emissões de gases de efeito estufa entre 2008 e 2012) e a majoração do preço mundial do petróleo devam impulsionar o consumo do álcool em vários países nas próximas décadas. No Brasil, os automóveis flex fluel estão dinamizando a demanda de álcool no país, dando maior poder de escolha e segurança ao consumidor. Contudo, talvez um dos maiores desafios da cadeia brasileira do álcool seja apurar, exatamente, as dimensões do mercado mundial de combustíveis e, a partir daí, viabilizar um planejamento estratégico de expansão da oferta de cana-de-açúcar e álcool para o futuro.

Sabe-se que cresceu a articulação de interesses entre os industriais do açúcar e do álcool por meio das associações nestes últimos 15 anos. $\mathrm{O}$ poder de negociação da indústria cresceu no interior do complexo agroindustrial sucroalcooleiro no Brasil (seja na região Centro-Sul ou Nordeste), visando aumentar o poder de negociação da categoria no processo de formulação das políticas públicas. É neste contexto que surge a União da Agroindústria Canavieira Paulista (UNICA), em 1997, 
numa tentativa de unificar as ações dos industriais do principal Estado produtor do país para lidar com o novo ambiente desregulamentado. Esta organização, que aglutina $80 \%$ das unidades de produção de açúcar e de álcool do Estado de São Paulo, possui elevado poder de representação e de negociação na esfera das discussões políticas relacionadas ao setor. A associação tem sido eficiente na representação das questões mais amplas do setor, como na luta pela quebra do protecionismo externo ao açúcar e álcool nacionais, na questão da definição do álcool na matriz energética brasileira e como interlocutora do setor junto ao Estado (MELLO, 2004).

Sobre um dos questionamentos postos (se há a necessidade de um momento de paradigma subvencionista para o biodiesel?), vale dizer que o custo maior de produção do biodiesel em relação aos derivados do petróleo exige incentivo tributário. Outrossim, garantir a competitividade do biodiesel perante o óleo diesel de petróleo, tendo em vista os elevados custos de produção deste biocombustível, é outro problema. Conforme analisado, desconsiderando-se eventuais subsídios públicos, as atuais tecnologias de fabricação da bioenergia, ainda imaturas, só seriam efetivamente competitivas se o barril de petróleo atingisse a marca de 60 dólares/barril. Portanto, a demanda de biodiesel para os próximos anos estará assegurada desde que o preço final do óleo diesel para o consumidor não sofra alterações em função da mistura do biocombustível, o que só será possível se as empresas produtoras contarem com isenções fiscais (inclusive para empresas da região CentroSul, responsável por $44 \%$ do consumo do diesel importado). Isto não impede de realizarem investimentos em $\mathrm{P} \& \mathrm{D}$ para viabilizar a produção a custos mais baixos.

Outra questão a ser avaliada é o real potencial da agricultura familiar, foco do Programa do governo, para atender à produção necessária de biodiesel. Até o momento, cerca de 20 mil famílias das regiões Norte e Nordeste foram inseridas na cadeia produtiva do biocombustível, produzindo oleaginosas e vendendo para usinas (que contam com benefícios fiscais, linhas de financiamento especiais do BNDES e autorização para participar dos leilões da ANP - em que o requisito é a aquisição de uma quantidade mínima de matérias-primas destas unidades familiares). Contudo, o problema desta opção do governo pelo desenvolvimen- 
to regional e pela inclusão social é o elevado custo de infra-estrutura logística. Como a maior parte das unidades de produção está localizada no Norte-Nordeste, e os centros de mistura do biodiesel no diesel de petróleo e o mercado consumidor do combustível estão no Centro-Sul, os custos de distribuição serão elevados, afetando a competitividade do produto. Uma possibilidade seria destinar a produção local para substituir o diesel usado na geração de energia elétrica, deixando a produção para combustível para as usinas que estão instaladas no Centro-Sul.

A questão tecnológica ora assinalada remonta a um outro questionamento (poderá o biodiesel ter no futuro próximo o seu momento de paradigma tecnológico?). No caso do biodiesel, embora vários projetos de construção de usinas de processamento estejam em curso, até o momento a produção é baixa. Por outro lado, a diversidade de alternativas de matérias-primas, os elevados custos de produção do biocombustível, o ambiente de incertezas, a falta de definição da política oficial de preços por parte do Governo e a insuficiência de incentivos fiscais em algumas regiões (como no Centro-Sul, responsável por $44 \%$ do consumo do diesel importado), sugerem dificuldades para a ocupação da capacidade instalada destes projetos, o que pode prejudicar o suprimento da demanda prevista para os próximos anos. Neste contexto, dentre os principais desafios a serem enfrentados está a necessidade de elevados investimentos em P\&D, voltados para o desenvolvimento de tecnologias de produção agrícola, com a definição de plantas mais aptas, sistemas de produção eficientes e definição de regiões com potencial para a produção. Há, também, necessidade de investimentos em novas tecnologias industriais, que transformem os produtos agrícolas em biodiesel. Se esta questão tecnológica não for solucionada, a margem de lucro dos produtores será pequena, em função dos custos elevados de produção, e poderá desestimular a produção nacional.

O fato é que para viabilizar o programa do biodiesel nos moldes como foi proposto, focando também na agricultura familiar, a orquestração de interesses precisa dar conta das disfunções que existem e podem vir a existir nesta cadeia que está se formando, como neste caso da distribuição e comercialização do produto. Além disso, o PNPB tem que ser aprofundado, contando efetivamente com o apoio do BNDES para financiamentos, da ANP para a realização de leilões, que são uma 
forma de dar legitimidade ao Programa, além de políticas públicas que possam resultar na promoção da gestão integrada da agricultura familiar, isto é, garantindo mercado para estes produtores.

A questão central (álcool combustível e biodiesel: quo vadis?) foi motivadora deste estudo, uma resposta única para tamanha indagação nos parece inoportuna ou talvez utópica ("Em Economia, a sabedoria tem dúvidas, a ignorância tem certeza” - Eugen von Böhm-Bawerk). Entretanto, alguns posicionamentos foram feitos neste trabalho, que seguiu um determinado rumo teórico-metodológico, num contexto de muitas outras diretrizes possíveis. Não obstante, se este trabalho propiciar ganhos para o debate acerca do álcool combustível e biodiesel, o mesmo estará cumprindo um dos nobres papéis da investigação, isto é, estimular/enriquecer a discussão científica, seja no âmbito da academia ou fora dela.

\section{Referências bibliográficas}

ALVES, L. R. A. Transmissão de preços entre produtos do setor sucroalcooleiro do Estado de São Paulo. Piracicaba, 2002. 117f. Dissertação (M.S.). ESALQ/USP.

ANFAVEA. Disponível em: < http://www.anfavea.com.br > Acesso em: 01 ago. 2006.

BELIK, W. Agroindústria processadora e política econômica. Campinas, 1992. 219p. Tese (Doutorado) - IE/UNICAMP.

F.O. LICHT. World Ethanol \& Biofuels Report. Várias edições. 2005

FERNANDES, E. S. L.; COELHO, S. T. (Orgs.). Perspectivas do álcool combustível no Brasil. São Paulo: USP - IEE, 1996. 166p.

MARSCHALL, C. R.; RISSARDI JÚNIOR, D. J.; STADUTO, J. A. R.; SHIKIDA, P. F. A. As políticas setoriais na agroindústria canavieira paranaense: um enfoque neocorporativista. Redes, Santa Cruz do Sul, v.10, n.1, p.43-65, jan./abr. 2005.

MELLO, F. O. T. As metamorfoses da rede de poder agroindustrial sucroalcooleira paulista: da regulação estatal para a desregulamentação. São Carlos, 2004. 117f. Dissertação (M. S.) - Engenharia de Produção/UFSCar. 
MAPA. Plano Nacional de Agroenergia, outubro/2005.

MINISTÉRIO DE MINAS E ENERGIA. Balanço Energético Nacional. 2005.

MOREIRA, E. F. P. Expansão, concentração e concorrência na agroindústria canavieira em São Paulo: 1975 a 1987. Campinas, 1989. 119p. Dissertação (M. S.) - IE/UNICAMP.

PAULILLO, L. F. Análise organizacional em redes de recursos de poder: contribuições para os estudos da concorrência, das decisões estratégicas e das políticas públicas. In: FUSCO, J. P. (org.) Tópicos Emergentes em Engenharia de Produção - volume 1. São Paulo: Arte \& Ciência, 2002. p. $27-58$

PAUliLlO, L. F.; MELLO, F. O. T.; VIAN, C. E. F. Análise da competitividade das cadeias de agroenergia no Brasil. In: BUAINAIN, A. M.; BATALHA, M. O. (Coord.). Análise da competitividade das cadeias agroindustriais brasileiras. São Carlos: DEP-UFSCAR/IE-UNICAMP, fev. 2006. 119 p. (Projeto MAPA/IICA).

RAMOS, P. Agroindústria canavieira e propriedade fundiária no Brasil. São Paulo: HUCITEC, 1999. 243p.

RENEWABLE FUELS ASSOCIATION. Ethanol Report. 2004. 20 p. Disponível em: < http://ethanolrfa.org > . Acesso em: 01 ago. 2006.

SAES, M. S. M. A racionalidade econômica da regulamentação no mercado brasileiro de café. São Paulo, 1995. 166p. Tese (Doutorado) - FEA/USP.

SHIKIDA, P. F. A. A evolução diferenciada da agroindústria canavieira no Brasil de 1975 a 1995. Piracicaba, 1997. 191p. Doutorado - ESALQ/USP.

SHIKIDA, P. F. A.; MORAES, M. A. D. de; ALVES, L. R. A. Agroindústria canavieira do Brasil: intervencionismo, desregulamentação e neocorporatismo. Revista de Economia e Agronegócio, Viçosa (MG), v.2, n.3, p.361-382, jul./set. 2004.

SOTO, B. F. Da indústria do papel ao complexo florestal no Brasil: o caminho do corporatismo tradicional ao neocorporatismo. Texto para Discussão. UNICAMP/IE, n. 14, p.1-48, jan. 1993. 
STREECK, W.; SCHMITTER, P. C. Community, market, state - and associations? The prospective contribution of interest governance to social order. In: STREECK, W.; SCHMITTER, P. C. (Edts.). Private interest government: beyond market and state. London: Sage, 1985. p. 1-29.

UNICA. Produção e uso do etanol combustível no Brasil: respostas às questões mais freqüentes. São Paulo: Única, 2007. 68p.

VIAN, C. E. de F. Agroindústria canavieira: estratégias competitivas e modernização. Campinas: Átomo, 2003. 216p.

WILSON, D. C.; BUTLER, R. J. Corporation in the British voluntary sector. In: STREECK, W.; SCHMITTER, P. C. (Edts.). Private interest government: beyond market and state, London: Sage, 1985. p. 72-86.

Recebido em agosto de 2006 e revisto em junho de 2007. 